\title{
KONTYNUACJA „TEKI KOMISJI HISTORYCZNEJ”
}

Wydawcą „Teki Komisji Historycznej” jest obecnie Towarzystwo Naukowe Katolickiego Uniwersytetu Lubelskiego Jana Pawła II, ale jej początki to Polska Akademia Nauk Oddział w Lublinie i rok 2004. Środowisko historyczne Oddziału zainicjowało wówczas wydawanie rocznika „Teka Komisji Historycznej PAN Oddział w Lublinie". W ciągu kilkunastu kolejnych lat pismo zyskało renomę nie tylko regionalną, ale także krajową - lubelski oddział PAN upowszechniał je, rozsyłał egzemplarze obowiązkowe do szesnastu bibliotek, a na prośbę zainteresowanych - także do ośrodków naukowych za granicą, m.in. w Anglii, Belgii i Rosji. W 2017 r. Akademia ograniczyła dofinansowanie dla tego rodzaju wydawnictw w kraju, w tym czasopism oddziału w Lublinie, co dotyczyło także „Teki”. Czasopismo przetrwało dzięki staraniom redaktora wielu tomów, Pani Profesor Ewy M. Ziółek z Instytutu Historii KUL, oraz decyzji Towarzystwa Naukowego KUL o włączeniu go do swoich wydawnictw. Porozumienie zainteresowanych stron Towarzystwa Naukowego KUL i Polskiej Akademii Nauk - otworzyło nowe perspektywy. Jeszcze w roku 2018 ukazał się tom piętnasty, sygnowany wspólnie przez PAN Oddział w Lublinie i TN KUL, a obecny i kolejne będą już wychodzić jedynie pod szyldem Towarzystwa Naukowego KUL. W czasopiśmie pozostał ten sam skład Komitetu Naukowego, układ tematyczny i format; zmodyfikowano tylko zewnętrzną szatę graficzną oraz tytuł. Obecnie jest to „Teka Komisji Historycznej Towarzystwa Naukowego KUL". Tradycyjnie czasopismo pozostaje otwarte także dla kręgów młodych naukowców.

Życzymy zarówno „Tece”, jak i Redakcji Naukowej oraz Towarzystwu Naukowemu KUL, a także autorom udanego startu w nowej odsłonie.

W imieniu Komitetu Naukowego „, Teki Komisji Historycznej” Redaktor Naczelny Profesor Eugeniusz Niebelski Lublin, 6 listopada 2019 r. 